\title{
Article
}

http://dx.doi.org/10.11646/phytotaxa.167.2.4

\section{A new species in the lichen genus Vahliella from the Canary Islands, including a key to Vahliellaceae, Pannariaceae, and Coccocarpiaceae in Macaronesia}

\author{
ISRAEL PÉREZ-VARGAS ${ }^{1}$, CONSUELO HERNÁNDEZ-PADRÓN ${ }^{1}$, P. L. PÉREZ DE PAZ ${ }^{1}$, P. P. G. VAN DEN \\ BOOM $^{2} \&$ P. M. JØRGENSEN ${ }^{3}$ \\ ${ }^{1}$ Departamento de Biología Vegetal (Botánica), Facultad de Farmacia, Universidad de La Laguna, c/ Astrofísico Sánchez s/n E-38071 \\ Tenerife, Canary Islands, Spain \\ ${ }^{2}$ Arafura 16, 5691 JA, Son, The Netherlands \\ ${ }^{3}$ Department of Natural History, University museum of Bergen, Allégt 41, Box 7800, N-5020 Bergen, Norway
}

\begin{abstract}
Vahliella isidioidea, found on consolidated soil in the laurel forest from the Canary Islands is described as new to science. A description of the species is given together with notes on its chemistry, distribution, ecology and taxonomy. Possible related lichen taxa are discussed briefly and a key to the Macaronesian species of Vahliella and morphologically related species is also provided.
\end{abstract}

Key words: Canary Islands, biodiversity, taxonomy, Vahliellaceae

\section{Introduction}

The genus Vahliella P. M. Jørg. was recently described to accommodate the subgenus Micropannaria P. M. Jørg. of Fuscopannaria P. M. Jørg. (Jørgensen 2008). Currently, the genus Vahliella includes eight species in the Northern Hemisphere, centered in North America but also found in Europe and India (Jørgensen 2009), and it is characterized by: a squamulose, mainly greyish-brownish thallus; sessile apothecia with variable thalline exciple, in some apothecia not at all developed, and with a likewise variable but always present proper margin; a hemiamyloid hymenium, unbranched, septate paraphyses with pigmented apices; 8-spored asci with sheet-like apical structures that are persistently I+ bluegreen; and non-septate, ellipsoid ascospores, lacking epispore but often with internal oil droplets (Jørgensen 2008). Molecular studies have shown that Vahliella differs so much from Fuscopannaria that it cannot even be placed in the Pannariaceae, and the family Vahliellaceae was recently segregated (Wedin et al. 2011). The distinctiveness of Fuscopannaria from the other genera in the Pannariaceae has been proved, as well the integration of Moelleropsis nebulosa (Hoffm.) Gyeln. into Fuscopannaria (Ekman \& Jørgensen 2002, Ekman et al. in prep). We support the proposal to conserve the name Fuscopannaria against Moelleropsis (Jørgensen et al. 2013).

Vahliellaceae is barely represented in Macaronesia. According to Sánchez-Pinto \& Rodríguez (2005), there is no species of the family in Cape Verde. In the checklist for the Azores, only Vahliella atlantica (P. M. Jørg. \& P. W. James) P. M. Jørg. and V. leucophaea (Vahl) P. M. Jørg. are cited (Flores Rodríguez \& Aptroot 2005; Hafellner 1995, 2008). From Madeira there is only one species published, V. leucophaea (Carvalho et al. 2008; Hafellner 1995, 2008), but $V$. atlantica is present in this archipelago (Jørgensen com. pers.). From the Canary Islands, only V. saubinetii (Mont.) P. M. Jørg. and $V$. atlantica are reported with certainty (Schumm 2008; Jørgensen com. pers.). The presence of $V$. leucophaea in the Canaries is very doubtful (Hafellner 2008).

The Macaronesian Region is characterized by high biodiversity and endemism in a vast array of organisms (Juan et al. 2000) and forms part of one of the 25 world biodiversity hotspots (Myers et al. 2000). The Canary Islands play a key role within this region (Médail \& Quézel 1997, 1999). The most recent revision of the lichen and lichenicolous biota of the Canaries lists more than 1600 species for an area of just $7447 \mathrm{~km}^{2}$ (Hernández Padrón \& Pérez-Vargas 2010). Nevertheless, new records arise and new species continue to be described from this region (Giralt $\&$ van den Boom 2011; van den Boom \& Ertz 2012; Pérez-Vargas et al. 2012, 2013; Pérez-Vargas \& Pérez-Ortega 2014), 


\section{Acknowledgements}

The first author is greatly obliged to the Cajacanarias Bancacívica / Fundación Global Nature for supporting him with a grant. Alexis Dorta is thanked for his helped in the field.

\section{References}

Calballal, R., Paz-Bermúdez, G. \& Valcárcel, C.P. (2007) The genera Coccocarpia (Coccocarpiaceae, Ascomycota), Degelia and Erioderma (Pannariaceae, Ascomycota), in the Iberian Peninsula. Nova Hedwigia 85: 51-62. http://dx.doi.org/10.1127/0029-5035/2007/0085-0051

Calballal, R., Paz-Bermúdez, G., Valcárcel, C.P. \& López de Silanes, M.E. (2010) Pannariaceae. Flora Liquenológica Ibérica VI. Sociedad Española de Liquenología. Pontevedra, España.

Carvalho, P., Figueira R. \& Jones, M.P. (2008) The lichens and lichenicolous fungi (Fungi) of the Madeira and Sevagens archipelagos In: Borges, P.A.V., Abreu, C., Aguiar, A.M.F., Carvahlo, P., Jardim, R., Melo, I., Oliveira, P., Sérgio, C., Serrano, A.R.M. \& Vieira, P. (eds) A list of the terrestrial fungi, flora and fauna of Madeira and Selvagens archipelagos. Direcçao Regional do Ambiente da Maderia and Universidade dos Açores, Funchal and Angra do Heroísmo. pp. 95-122.

Culberson, C.F. (1972) Improved conditions and new data for the identification of lichen products by a standardized thin-layer chromatographic method. Journal of Chromatography 72: 113-125.

Culberson, C.F., Culberson, W.L. \& Johnson, A. (1981) A standardized TLC analysis of $\beta$-orcinol depsidones. Bryologist 84: $16-29$.

http://dx.doi.org/10.2307/3242974

Del Arco Aguilar, M.J., González-González, R., Garzón-Machado, V. \& Pizarro-Hernández, B. (2010) Actual and potential natural vegetation on the Canary Islands and its conservation status. Biodiversity and Conservation 19: 3089-3140.

Elix, J.A. \& Ernst-Russell, K.D. (1993) A Catalogue of Standardized Thin Layer Chromatographic Data and Biosynthetic Relationships for Lichen Substances, 2nd Edition. Canberra: Australian National University.

Ekman, S. \& Jørgensen, P.M. (2002) Towards a molecular phylogeny for the lichen family Pannariaceae (Lecanorales, Ascomycota). Canadian Journal of Botany 80: 625-634.

Flores Rodrigues, A.F. \& Aptroot, A. (2005) New data and corrections to the List of Lichens and Lichenicolous fungi from the Azores. In: Borges, P.A.V., Cunha, R., Gabriel, R., Martins, A.F., Silva, L. \& Vieira V. (eds.) A list of terrestrial fauna (Mollusca and Arthropoda and flora (Bryophyta, Pteridophyta and Spermatophyta) from the Azores Direcçao Regional do Ambiente and Universidade dos Açores, Horta, Angra do Heroísmo and Ponta Delgada. pp: 231-247.

Giralt, M. \& van den Boom, P.P.G. (2011) The genus Buellia s.l. and some additional genera of Physciaceae in the Canary Islands. Nova Hedwigia 92: 29-55. http://dx.doi.org/10.1127/0029-5035/2011/0092-0029

Hafellner, J. (1995) A new checklist of lichens and lichenicolous fungi of Insular Laurimacaronesia including a lichenological bibliography for the area. Fritschiana 5: 1-132.

Hafellner, J. (2008) Additions and corrections to the Checklist and bibliography of lichens and lichenicolous fungi of Insular Laurimacaronesia. IV. Fritschiana 64: 1-28.

Hernández Padrón, C.E. \& Pérez-Vargas, I. (2010) Lichenes, Lichenicolous Fungi. En: Arechavaleta, M., Rodríguez „S., Zurita, N. \& García, A. (coord.) Lista de especies silvestres de Canarias. Hongos, plantas y animales terrestres. 2009. Consejería de Medio Ambiente y Ordenación Territorial. Gobierno de Canarias. pp: 71-105.

Jørgensen, P.M. (1978) The lichen family Pannariaceae in Europe. Opera Botanica 45: 1-123.

Jørgensen, P.M. (1994) Studies in the lichen family Pannariaceae VI. The taxonomy and phytogeography of Pannaria Del. s. lat. Journal of the Hattori Botanical Laboratory 76: 197-206.

Jørgensen, P.M. (2000) Survey of the lichen family Pannariaceae on the American continent, North of Mexico. Bryologist 103: $670-704$.

Jørgensen, P.M. (2005) A new Atlantic species in Fuscopannaria, with a key to its European species. Lichenologist 37: $221-225$. Jørgensen, P.M. (2008) Vahliella, a new lichen genus. Lichenologist 40: 221-225.

Jørgensen, P.M. (2009) Vahliella In: Smith., C.W., Aptroot, A., Coppins B.J., Fletcher, A., Gilbert, O.L., James, P.W. \& Wolseley, P.A. (eds.). Lichen Flora of Great Britain and Ireland. British Lichen Society. London pp 930-931.

Jørgensen, P.M. (2013) Proposal to conserve the name Fuscopannaria against Moelleropsis (lichenized Ascomycota). Taxon 63: 629. 
Jørgensen, P.M. \& Johnsen, J.I. (2006) Fuscopannaria atlantica new to Scandinavia. Graphis Scripta 18: 16-18.

Juan, C., Emerson, B.C., Oromí, P. \& Hewitt, G.M. (2000) Colonization and diversification: towards a phylogeo- graphic synthesis for the Canary Islands. Trends in Ecology and Evolution 15: 104-109.

Lumbsch, H.T., del Prado, R. \& Kantvilas, G. (2005) Gregorella, a new genus to accommodate Moelleropsis humida and a molecular phylogeny of Arctomiaceae. Lichenologist 37: 291-302. http://dx.doi.org/10.1017/s002428290501532x

Médail, F. \& Quézel, P. (1997) Hot-Spots analysis for conservation of plant biodiversity in the Mediterranean basin. Annals of the Missouri Botanical Garden 84: 112-127.

Médail, F. \& Quézel, P. (1999) Biodiversity hotspots in the Mediterranean basin: setting global conservation priorities. Conservation Biology 13: 15140-1513.

Myers, N., Mittermeier, R.A., Mittermeier, C.G., da Fonseca, G.A.B. \& Kent, J. (2000) Biodiversity hotspots for conservation priorities. Nature 403: 853-858.

Orange, A., James, P.W. \& White, F.J. (2001) Microchemical methods for the identification of lichens. British Lichen Society. 101 pp.

Paz-Bermúdez, G., Calballal, R. \& López de Silanes, M.E. (2008) The genus Fuscopannaria P.M. Jørg. (Pannariaceae, lichenized Ascomycota) in the Iberian Peninsula. Candollea 63: 269-280.

Pérez-Vargas, I., Hernández-Padrón, C., Pérez de Paz, P.L. \& Elix, J.A. (2012) Pertusaria etayoi (lichenized Ascomycota: Pertusariaceae) a new lichen species from the Canary Islands. Lichenologist 44: 333-337. http://dx.doi.org/10.1017/s0024282911000934

Pérez-Vargas, I., Etayo, J. \& Hernández Padrón, C. (2013) New species of lichenicolous fungi from the Canary Islands. Phytotaxa 99: 58-64.

Pérez-Vargas, I. \& Pérez-Ortega, S. (2014) A new endemic Ramalina from the Canary Islands. Phytotaxa 159: $269-278$.

Sánchez-Pinto, L. \& Rodríguez, S. (2005) Lichenes. En: Arechavaleta, M., Zurita, N., Marrero, M.C. \& Martín, J.L. (eds.) Lista preliminar de especies silvestres de Cabo Verde (hongos, plantas y animales terrestres) 2005. Consejería de Medio Ambiente y Ordenación Territorial, Gobierno de Canarias. pp.27-33.

Schumm, F. (2008) Flechten Madeiras, der Kanaren und Azoren. Wangen, Germany. 294+19 pp.

Van den Boom, P.P.G. \& Ertz, D. (2012) Lichens and lichenicolous fungi from El Hierro (Canary Islands), a survey, including five new species. Cryptogamie, Mycologie 33: 59-97.

http://dx.doi.org/10.7872/crym.v33.iss1.2012.059

Vondrák, J., Palice, Z., Mares, J. \& Kocourkova, J. (2013) Two superficially similar lichen crusts, Gregorella humida and Moelleropsis nebulosa, and a description of the new lichenicolous fungus Llimoniella gregorellae. Herzogia 26: 31-48. http://dx.doi.org/10.13158/heia.26.1.2013.31

Wedin, M., Jørgensen, P.M. \& S. Ekman (2011) Vahliellaceae, a new family of cyanobacterial lichens (Peltigerales, Ascomycetes). Lichenologist 43: 67-71.

http://dx.doi.org/10.1017/s0024282910000642 